\title{
Evaluation and stability analysis of some bread wheat genotypes under heat stress
}

\author{
Ali $^{1}$ M. A., M. S. Hassan' ${ }^{1}$, M. M. Zakaria ${ }^{2}$ and H. M. A. Ahmed ${ }^{1}$ \\ ${ }^{I}$ Department of Agronomy, Faculty of Agriculture, South Valley University, Qena, Egypt. \\ ${ }^{2}$ Wheat Research Institute, Agriculture Reseach Center, Giza, Egypt.
}

\section{Abstract}

This study was conducted at Kom-Mombo Agricultural Research Station, Aswan governorate, ARC, Egypt to study the performance and stability analysis of some wheat genotypes under heat stress. Twelve genotypes of bread wheat were investigated under six environments; two years (2017/2018 and 2018/2019 seasons) and three sowing dates (normal $\left(D_{1}\right), 23^{\text {rd }}$ of Nov., late $\left(D_{2}\right), 13^{\text {th }}$ of Dec. and very late $\left(D_{3}\right), 16^{\text {th }}$ of January). The differences among years, dates and genotypes were significant $(\mathrm{p}<0.01)$ for heading date, plant height, 100-grain weight and grain yield. All first order interactions were significant for most studied traits. Mean squares due to interaction between genotypes, sowing dates and years were significantly for heading date and grain yield. The early sowing outyielded late and vey late one by 17.79 and $63.50 \%$, respectively. Delaying sowing date reduced all traits under investigated. Five genotypes were less susceptible (heat susceptibility index less than one) and less sensitive (less than one) for heat stress. The stability analysis for grain yield exhibited that the intermediate yielding genotypes(Masr 1, Masr 2, Sids 12, Sids 13, Sids 14, BAG\#1 and $\mathrm{KACHU}^{* 2}$ ) were stable and ranged in yield from 8.90 to $12.28 \mathrm{Ard} / \mathrm{fed}$.). However, the genotype Masr 1was stable and high in grain yield. While, the highest yielding genotype; Gimmiza 11 was unstable.

Key words: Wheat; Evaluation; Stability; Interaction.

\section{Introduction}

Wheat (Triticum aestivum L.) is one of the leading cereal crops and used as a staple for human not only in Egypt but also all over the world. Beside staple food for human beings, wheat straw is a good source of feed for a large population of animals (buffaloes, cow and cattle) in Egypt and also used for manufacturing of straw boards, papers and other pulp Tammam and Abd-El-Rady (2011) and Hakim et al (2012) stated that number of days to heading tended to decrease by

\footnotetext{
*Corresponding author: M.A. Ali

Email: Mohamed agr@yahoo.com

Received: November 11, 2020;

Accepted: December 19, 2020;

Published: December 24, 2020.
}

products. The sowing time plays an important role among various agronomic factors, which influencing the quality and yield of wheat. Normal sowing has longer growth during which consequently provides an opportunity to accumulate more biomass as compared to late sowing, hence manifested in higher grain and biological yields (Singh and Pal, 2003).

delaying sowing date. Dokuyucu et al (2004) and Asmaa et al (2018) found a significantly decrease, in heading date, plant height, 100-grain weight and grain yield/plant by delaying sowing date. 
Al-Otayk (2010), Tammam and Abd-ElRady (2011), Hamam et al (2015), Bankar et al (2018), Patel et al (2019) and Ali et al (2020) mentioned that plant height, 100grain weight and grain yield were the greatest in wheat sown in mid-November compared to the other dates. Tahir et al (2009) and Bachhao et al (2018) reported that sowing date on $1^{\text {st }}$ of December gave maximum grain yield compared to late sowing on $30^{\text {th }}$ of Dec. Shahzad et al (2002) and Shah et al (2006) reported that sown on $1^{\text {st }}$ of November gave maximum mean values of plant height, 1000-grain weight and grain yield compared with other sowing dates.

Significant effect of heat stress in reduction of plant height, number of kernels/plant, 100-kernels weight, and grain yield was registered by Oliveira et al. (2011), Hamda and Ibrahim (2016) and Jaiswal et al (2017).

Some genotypes showed great heat tolerance and gave the highest grain yield per plant under both sowing dates was observed Khajuria et al (2016) and Ali et al (2020). Heritability estimates were moderate for grain yield (Sharma et al (2010), Ahmad et al, 2017 and Mwadzingeni et al, 2018). High heritability in broad sense estimates for days to heading (Singh et al, 2013 and Elbasier et al, 2019).

Stability parameters have been proposed to identify superior genotypes under normal and stress conditions, so, the breeder must be select the productive and stable genotypes under poor and normal environments (Guttieri et al, 2001). Berke et al (1992) demonstrated that stability of quantitative traits is influenced by one or more major loci. The objective of this study to evaluate 12 bread wheat genotypes of diverse origin under three sowing dates for yielding ability and its components and to estimate the stability for grain yield and its components of the genotypes to identify the most genotype which behave consistently over a wide range of environments.

\section{Materials and Methods}

This research was carried out during the 2017/2018 and 2018/2019 at Kom-Mombo Agricultural Research Station, Aswan governorate, ARC, Egypt to evaluated 12 genotypes of bread wheat (Triticum aestivam L.). The local name, pedigree and origin of these genotypes are presented in Table 1. Minimum, maximum and daily temperatures as well as relative humidity at Aswan are given in Table 2.

The twelve genotypes of bread wheat were evaluated under six environments; two years (2017/2018 and 2018/2019) and three sowing dates $\left[23^{\text {rd }}\right.$ of Nov. (normal sowing date; $\mathrm{D}_{1}$ ), $16^{\text {th }}$ of Dec. (late sowing date; $\mathrm{D}_{2}$ ) and $16^{\text {th }}$ of January (very late sowing date; $\left.D_{3}\right)$ ]. The experiment designed in split-plot arranged in a randomized complete block design (RCBD) with three replications. The main plot treatments comprised of three sowing dates. However, the sub-plot treatments were allocated to 12 genotypes. Total area of the sub-plot was $4.80 \mathrm{~m}^{2}$; each sub-plot consists of six rows of $4 \mathrm{~m}$ long and $20 \mathrm{~cm}$ spacing between 2 rows. The recommended agronomic practices were followed for god crop and competitive crop stand.

Data were recorded on days to heading, plant height, number of grains/plant, biological yield/plant, 100-grain weight and grain yield/plant on sub-plot basis for each genotype. 
Table 1 . The local name, pedigree and origin of the used genotypes.

\begin{tabular}{|c|c|c|c|}
\hline No. & Name & Pedigree & Origin \\
\hline 1 & Masr 1 & $\begin{array}{l}\text { OASIS/SKAUZ//4*BCN/3/2*PASTORCMSS00Y01881T-050M-030Y-030M- } \\
\text { 030WGY-33M-0Y-0S }\end{array}$ & Egypt \\
\hline 2 & Masr 2 & SKAUZ/BAV92CMSS96M03611S-1M-010SY-010M-010SY-8M-0Y-0S & Egypt \\
\hline 3 & Masr 3 & $\begin{array}{l}\text { ROHF07*2/KIRITICGSS05B00123T-099T-0PY-099M-099NJ-6WGY-0B-0BGY- } \\
\text { 0GZ }\end{array}$ & Egypt \\
\hline 4 & Sids 12 & $\begin{array}{l}\text { BUC//7C/ALD/5/MAYA74/ON//1160,1473//BB/GII14/CHAT"s"/6/ } \\
\text { MAYA/VUL// }\end{array}$ & Egypt \\
\hline 5 & Sids 13 & $\begin{array}{l}\text { KAUZ//TSI/SNBICW94-0375-4AP-2AP-030AP-0APS-3AP-0APS-050AP-0AP- } \\
\text { SD }\end{array}$ & Egypt \\
\hline 6 & Sids 14 & SW8488*2/KUKUNACGSS01Y00081T-099M-099Y-099M-099B-9Y-0B-0SD. & Egypt \\
\hline 7 & $\begin{array}{l}\text { BAJ\#1//WAXING } \\
\text { /PIHA }\end{array}$ & CMSS10Y00027S-099Y-099NJ-099NJ-6WGY-0B & ICARDA \\
\hline 8 & Giza 171 & $\begin{array}{l}\text { ROLF07*2/KTRITARICGSS05B00123T-099TOPY-099M-099NJ-6WGY-0B- } \\
\text { 0EGY }\end{array}$ & Egypt \\
\hline 9 & Sakha 95 & PASTOR//SITE/MO/3/CHEN/AEGILOPSSQUARROSA(TAUS)//BCN/4/WBLLI & Egypt \\
\hline 10 & $\begin{array}{l}\text { KACHU*2/CIRNO } \\
\text { C2008 }\end{array}$ & CMSS10B0120IT-099TOPY-099M-0SY-31M-0WGY & ICARDA \\
\hline 11 & Gimmaza 11 & $\begin{array}{l}\text { BOW"S"/KVZ//7C/SER182/3/GIZA 168/SAKHA61.GM7892-2GM-1GM-2GM- } \\
\text { 1GM-0GM. }\end{array}$ & Egypt \\
\hline 12 & Shandaweel 1 & $\begin{array}{l}\text { SITE//M0/4/NAC/TH.AC//3*PVN/3/MIRLO/BUF.CMSS03B00567S-72Y-010M- } \\
\text { 010Y-010M-0HTY-0SH }\end{array}$ & Egypt \\
\hline
\end{tabular}

\section{C- Heatsusceptibility index and the} sensitivity test:

Estimates of heat susceptibility index (HSI) for grain yield was computed according to the method of Fischer and Maurer (1978). The sensitivity was computed according to Falconer (1990).

\section{Statistical analysis:}

The obtained data were subjected to analysis of variance of split-plot design according to Gomez and Gomez (1984). The combined analysis was performed by MSTAT-C Computer program after carrying out homogeneity test. Differences among means were assessed by the revised least significant differences (LSD') at 5 and $1 \%$ levels of probability according to (ElRawi and Khalafalla; 1980).

\section{Components of variances}

The phenotypic $\left(\sigma^{2} p\right)$ and genotypic $\left(\sigma^{2} \mathrm{~g}\right)$ variance were estimated according to Al-Jibouri et al (1958). According to Comstock and Robinson (1952), broad sense heritability estimates for grain yield and related traits as the ratio of genotypic variance $\left(\sigma^{2} \mathrm{~g}\right)$ to phenotypic variance $\left(\sigma^{2} p\right)$. 
Table 2. Minimum, maximum and mean daily temperature and humidity as well as relative humidity at Kom-Mombo from sowing to harvesting date in both seasons.

\begin{tabular}{|c|c|c|c|c|c|c|c|c|c|c|c|c|c|}
\hline \multirow{3}{*}{\multicolumn{2}{|c|}{ Month }} & \multicolumn{6}{|c|}{$2017 / 2018$} & \multicolumn{6}{|c|}{ 2018/2019 } \\
\hline & & \multicolumn{3}{|c|}{ temperature } & \multicolumn{3}{|c|}{ humidity } & \multicolumn{3}{|c|}{ Temperature } & \multicolumn{3}{|c|}{ Humidity } \\
\hline & & \multirow{2}{*}{$\begin{array}{c}\text { Mini. } \\
8.3\end{array}$} & \multirow{2}{*}{$\begin{array}{l}\text { Max. } \\
25.4\end{array}$} & \multirow{2}{*}{$\begin{array}{c}\begin{array}{c}\text { Daily } \\
\text { mean }\end{array} \\
16.9\end{array}$} & \multirow{2}{*}{$\begin{array}{l}\text { Mini. } \\
56.0\end{array}$} & \multirow{2}{*}{$\begin{array}{l}\text { Max. } \\
100.0\end{array}$} & \multirow{2}{*}{$\begin{array}{c}\begin{array}{c}\text { Daily } \\
\text { mean }\end{array} \\
78.0\end{array}$} & \multirow{2}{*}{$\begin{array}{l}\text { Mini. } \\
11.2\end{array}$} & \multirow{2}{*}{$\begin{array}{l}\text { Max. } \\
28.7\end{array}$} & \multirow{2}{*}{\begin{tabular}{|c|} 
Daily \\
mean \\
20.0
\end{tabular}} & \multirow{2}{*}{$\begin{array}{l}\text { Mini. } \\
27.0\end{array}$} & \multirow{2}{*}{$\begin{array}{l}\text { Max. } \\
68.0\end{array}$} & \multirow{2}{*}{$\begin{array}{c}\begin{array}{c}\text { Daily } \\
\text { Mean }\end{array} \\
47.5\end{array}$} \\
\hline Nov. & $\begin{array}{c}21- \\
30\end{array}$ & & & & & & & & & & & & \\
\hline & Mean & 8.3 & 25.4 & 16.9 & 56.0 & 100.0 & 78.0 & 11.2 & 28.7 & 20.0 & 27.0 & 68.0 & 47.5 \\
\hline \multirow{4}{*}{ Dec. } & $1-10$ & 9.9 & 28.1 & 19.0 & 48.0 & 100.0 & 74.0 & 6.8 & 23.7 & 15.3 & 28.0 & 91.0 & 59.5 \\
\hline & $\begin{array}{l}11- \\
20\end{array}$ & 9.7 & 28.7 & 19.2 & 39.0 & 100.0 & 69.5 & 5.0 & 24.1 & 14.6 & 26.0 & 97.0 & 61.5 \\
\hline & $\begin{array}{l}21- \\
31\end{array}$ & 11.9 & 27.0 & 19.5 & 41.0 & 90.0 & 65.5 & 5.9 & 22.9 & 14.4 & 29.0 & 91.0 & 60.0 \\
\hline & Mean & 10.5 & 27.9 & 19.2 & 42.7 & 96.7 & 69.7 & 5.9 & 23.6 & 14.8 & 27.7 & 93.0 & 60.4 \\
\hline \multirow{4}{*}{ Jan. } & $1-10$ & 4.8 & 23.5 & 14.2 & 35.0 & 100.0 & 67.5 & 4.0 & 20.7 & 12.4 & 28.0 & 89.0 & 58.5 \\
\hline & $\begin{array}{l}11- \\
20\end{array}$ & 6.5 & 24.0 & 15.3 & 34.0 & 92.0 & 63.0 & 2.5 & 21.6 & 12.1 & 26.0 & 94.0 & 60.0 \\
\hline & $\begin{array}{l}21- \\
31\end{array}$ & 5.7 & 23.0 & 14.4 & 36.0 & 95.0 & 65.5 & 6.2 & 26.3 & 16.3 & 24.0 & 85.0 & 54.5 \\
\hline & Mean & 5.7 & 23.5 & 14.6 & 35.0 & 95.7 & 65.3 & 4.2 & 22.9 & 13.6 & 26.0 & 89.3 & 57.7 \\
\hline \multirow{4}{*}{ Feb. } & $1-10$ & 9.1 & 31.9 & 20.5 & 29.0 & 88.0 & 58.5 & 9.2 & 26.5 & 17.9 & 27.0 & 80.0 & 53.5 \\
\hline & $\begin{array}{l}11- \\
20\end{array}$ & 11.4 & 27.2 & 19.3 & 47.0 & 91.0 & 69.0 & 4.7 & 23.8 & 14.3 & 27.0 & 93.0 & 60.0 \\
\hline & $\begin{array}{l}21- \\
28\end{array}$ & 12.1 & 31.2 & 21.7 & 35.0 & 91.0 & 63.0 & 9.5 & 26.7 & 18.1 & 26.0 & 75.0 & 50.2 \\
\hline & Mean & 10.9 & 30.1 & 20.5 & 37.0 & 90.0 & 64.0 & 7.8 & 25.7 & 16.8 & 26.7 & 82.7 & 54.7 \\
\hline \multirow{4}{*}{ March } & $1-10$ & 11.9 & 35.1 & 23.5 & 32.0 & 95.0 & 63.5 & 6.9 & 26.8 & 16.9 & 23.0 & 74.0 & 48.5 \\
\hline & $\begin{array}{l}11- \\
20\end{array}$ & 12.8 & 34.7 & 23.8 & 35.0 & 93.0 & 64.0 & 10.1 & 29.9 & 20.0 & 22.0 & 60.0 & 41.0 \\
\hline & $\begin{array}{l}21- \\
31\end{array}$ & 17.2 & 36.1 & 26.7 & 42.0 & 75.0 & 58.5 & 13.2 & 30.6 & 21.9 & 24.0 & 55.0 & 39.5 \\
\hline & Mean & 14.0 & 35.3 & 24.7 & 36.3 & 87.7 & 62.0 & 10.1 & 29.1 & 19.6 & 23.0 & 63.0 & 43.0 \\
\hline \multirow{4}{*}{ April } & $1-10$ & 14.5 & 34.3 & 24.4 & 45.0 & 91.0 & 68.0 & 14.1 & 23.9 & 19.0 & 26.0 & 47.0 & 36.5 \\
\hline & $\begin{array}{l}11- \\
20\end{array}$ & 16.4 & 39.1 & 27.8 & 42.0 & 92.0 & 67.0 & 14.5 & 32.8 & 23.7 & 27.0 & 63.0 & 45.0 \\
\hline & $\begin{array}{l}21- \\
30\end{array}$ & 15.8 & 35.5 & 25.7 & 49.0 & 92.0 & 70.5 & 14.3 & 36.6 & 25.5 & 24.0 & 58.0 & 41.0 \\
\hline & Mean & 15.6 & 36.3 & 26.0 & 45.3 & 91.7 & 68.5 & 14.3 & 31.1 & 22.7 & 25.7 & 56.0 & 40.9 \\
\hline \multirow{3}{*}{ May } & $1-10$ & 22.8 & 42.2 & 32.5 & 43.0 & 86.0 & 64.5 & 19.4 & 39.9 & 29.7 & 24.0 & 48.0 & 36.0 \\
\hline & $\begin{array}{l}11- \\
20\end{array}$ & 20.5 & 40.5 & 30.5 & 23.0 & 54.0 & 38.5 & 18.8 & 40.8 & 29.8 & 26.0 & 53.0 & 39.5 \\
\hline & Mean & 21.65 & 41.35 & 31.5 & 33 & 70 & 51.5 & 19.1 & 40.35 & 29.75 & 25 & 50.5 & 37.75 \\
\hline
\end{tabular}

Meteorological Authority at Kom-Mombo, Aswan governorate, Egypt.

\section{$\underline{\text { Stability analysis }}$}

Stability analysis for all studied traits was carried out using Eberhart \&
Russell model (1966).

\section{Results and discussion}


The mean monthly temperature and relative humidity are given in Table 2 . Mean monthly temperature were almost different in both seasons of study except for the month of November. The December

\section{Analysis of variance}

The combined analysis of variance (Table 3) exhibited significant $\quad(\mathrm{P}<0.01)$ differences between years for all studied tested; heading date, plant height, 100grain weight and grain yield, indicating that the wide differences in climatic changes prevailing in the two seasons. The main effect of dates was significant $(\mathrm{P}<$ 0.01 ) for these traits, as it would be expected for early and late date of sowing. Moreover, the effect of sowing dates was more pronounced than that of years for all studied traits except grain yield. The first order interaction of year's $x$ dates was significant $(\mathrm{P}<0.01)$ for the studied traits except plant height, revealing that the effect of sowing date varied from year to another. The differences among genotypes were significant $(\mathrm{P}<0.01)$, showing that the presence of considerable genetic diversity among the genotypes for these traits. Mean squares due to interaction between genotypes, sowing dates and years for these traits were significant $(\mathrm{P}<0.01)$ except 100-grain weight was not significant under $\mathrm{Y} \times \mathrm{G}$ and $\mathrm{D} \times \mathrm{G}$, respectively. The second order interaction $\mathrm{Y} \times \mathrm{D} \times \mathrm{G}$ was significant for days to heading and grain yield. This reflects that the sensitivity of these genotypes to environmental changes suggesting the assessment of genotypes under different environments for identifying the best genotype(s) for particular environment as well as finding the stable ones over such array of conditions. A considerable variation among cultivars of wheat were to May months of 2017/2018 experiences 4 $-5^{\circ} \mathrm{C}$ higher temperature than the year 2018/2019. The mean monthly relative humidity was $8-28 \%$ higher in $2017 / 2018$ compared to 2018/2019.

reported by Shah et al (2006), Wajid et al (2006), Bankar et al (2018) and Ali et al (2020).

\section{Days to heading}

Results in Table 4 showed that the early sowing date gave 85.74 compared with 81.56 and 62.81 days resulted from late and very late sowing date, respectively. The average number of days to heading at second and third date was nearly early by 4 and 23 days, respectively. These results could be because heat units and the accumulated metabolites required for wheat flowering were reduced in the late and very late sowing dates. Over all environments, the average days to heading ranged from 71.72 for the genotype BAG\#1 to 81.00 for the genotype Masr 2 with an average of 76.70 days (Table 4). Data in Table 4 indicated that the genotype BAG\#1 was the earliest at all sowing dates, indicating that this genotype had accumulated desirable alleles for earliness and could be used in future breeding programs. On the other hand, the genotypes Masr 2 and Sids 14 were the latest under all sowing dates, indicating that these genotypes had accumulated desirable alleles for lateness. In general, the results indicate that genotypes early flower under late sowing date than under normal date. Similar results were observed by Wajid et al (2006), Bankar et al (2018), Mukherjee et al (2018), and Ali et al (2020).

\section{Plant height}


With respect to plant height, data in Table 4 illustrated that planting wheat early produced taller plants than late and very late planting. Over all environments, the genotype of wheat had significant effect on plant height, among the genotypes BAG\#1 $(92.7 \mathrm{~cm})$ was found shorter and Masr $2(106.9 \mathrm{~cm})$ was taller (Table 4). Average height required for

Table 3. Combined analysis of variance, genotypic $\left(\sigma^{2} g\right)$ and phenotypic $\left(\sigma^{2} p\right)$ variance and broad sense heritability $\left(\mathrm{h}_{\mathrm{b}}^{2}\right)$ of 12 genotypes over six environments for the studied traits.

\begin{tabular}{|c|c|c|c|c|c|}
\hline \multirow[b]{2}{*}{ S.O.V } & \multirow[b]{2}{*}{ d.f } & \multicolumn{4}{|c|}{ Mean squares } \\
\hline & & $\begin{array}{l}\text { Days to } \\
\text { heading }\end{array}$ & $\begin{array}{l}\text { Plant height } \\
\text { (cm) }\end{array}$ & $\begin{array}{l}\text { 100-grain } \\
\text { weight (g) }\end{array}$ & $\begin{array}{c}\text { Grain } \\
\text { yield/plant } \\
\text { (Ard./fed.) }\end{array}$ \\
\hline Years (Y) & 1 & $2845.63^{* *}$ & $4163.30^{* *}$ & $6.13^{* *}$ & $1982.53^{\text {** }}$ \\
\hline Error (a) & 4 & 3.39 & 31.62 & 0.40 & 2.76 \\
\hline Sowing dates (D) & 2 & $11041.14^{* * *}$ & $9967.76^{* *}$ & $21.35^{* *}$ & $1780.54^{* *}$ \\
\hline $\mathrm{Y} \times \mathrm{D}$ & 2 & $63.00^{* *}$ & 16.29 & $2.19^{* *}$ & $398.85^{* *}$ \\
\hline Error (b) & 8 & 3.05 & 15.74 & 0.18 & 2.50 \\
\hline Genotypes (G) & 11 & $111.57^{* *}$ & $415.57^{* *}$ & $2.10^{* *}$ & $22.30^{* *}$ \\
\hline $\mathrm{Y} \times \mathrm{G}$ & 11 & $12.80^{* *}$ & $48.87^{* *}$ & 0.09 & $17.60^{* *}$ \\
\hline $\mathrm{D} \times \mathrm{G}$ & 22 & $6.43^{* *}$ & $48.11^{* *}$ & $0.20^{*}$ & $4.80^{* *}$ \\
\hline $\mathrm{Y} \times \mathrm{D} \times \mathrm{G}$ & 22 & $11.65^{* *}$ & 22.27 & 0.12 & $9.45^{* *}$ \\
\hline Error (c) & 132 & 2.79 & 14.73 & 0.12 & 1.65 \\
\hline$\sigma^{2} \mathrm{~g}$ & - & 5.49 & 20.37 & 0.11 & 0.26 \\
\hline$\sigma^{2} \mathrm{p}$ & - & 6.42 & 25.28 & 0.15 & 0.81 \\
\hline $\mathrm{h}_{\mathrm{b}}^{2}$ & - & 0.86 & 0.81 & 0.73 & 0.32 \\
\hline
\end{tabular}

*, **; Significant at 0.05 and 0.01 levels of probability, respectively.

Table 4. Average performance of days to heading and plant height for the 12 genotypes under different sowing dates over two years.

\begin{tabular}{|c|c|c|c|c|c|c|c|c|c|}
\hline \multirow{2}{*}{ No. } & \multirow{2}{*}{ Genotypes } & \multicolumn{4}{|c|}{ Days to heading } & \multicolumn{5}{c|}{ Plant height (cm) } \\
\cline { 3 - 10 } & & $\mathrm{D}_{1}$ & $\mathrm{D}_{2}$ & $\mathrm{D}_{3}$ & Combined & $\mathrm{D}_{1}$ & $\mathrm{D}_{2}$ & $\mathrm{D}_{3}$ & Combined \\
\hline 1 & Masr 1 & 85.67 & 83.83 & 63.83 & 77.78 & 106.5 & 100.7 & 83.7 & 97.0 \\
\hline 2 & Masr 2 & 90.00 & 86.17 & 66.83 & 81.00 & 115.2 & 110.4 & 95.1 & 106.9 \\
\hline 3 & Masr 3 & 84.83 & 81.00 & 60.17 & 75.33 & 107.2 & 102.5 & 87.2 & 99.0 \\
\hline 4 & Sids 12 & 84.83 & 79.00 & 60.33 & 74.72 & 103.0 & 99.1 & 77.8 & 93.3 \\
\hline 5 & Sids 13 & 88.33 & 82.83 & 64.67 & 78.61 & 106.7 & 92.9 & 78.9 & 92.8 \\
\hline 6 & Sids 14 & 91.17 & 85.83 & 64.00 & 80.33 & 111.7 & 109.7 & 89.7 & 103.7 \\
\hline 7 & BAG \#1 & 79.33 & 74.50 & 61.33 & 71.72 & 99.1 & 96.9 & 82.0 & 92.7 \\
\hline 8 & Giza 171 & 84.50 & 81.83 & 63.33 & 76.56 & 108.1 & 107.7 & 86.6 & 100.8 \\
\hline 9 & Sakha 95 & 87.33 & 84.50 & 65.50 & 79.11 & 118.6 & 113.4 & 86.1 & 106.0 \\
\hline 10 & KACHU*2 & 83.67 & 78.83 & 59.50 & 74.00 & 103.6 & 103.3 & 86.8 & 97.9 \\
\hline 11 & Gimmaza 11 & 83.00 & 78.50 & 61.00 & 74.17 & 106.1 & 103.3 & 87.8 & 99.1 \\
\hline 12 & Shandaweel & 86.17 & 81.83 & 63.17 & 77.06 & 106.5 & 104.3 & 85.6 & 98.8 \\
\hline Mean & 1 & 85.74 & 81.56 & 62.81 & 76.70 & 107.7 & 103.7 & 85.6 & 99.0 \\
\hline RLSD $_{0.05}$ & & - & - & - & 1.09 & - & - & - & 2.48 \\
\hline RLSD & & - & - & - & 1.49 & - & - & - & 3.40 \\
\hline
\end{tabular}

height was $99.0 \mathrm{~cm}$. Heat stress exerts its inhibitory effect on cell elongation and the accompanied by a reduction in plant height. These results are in accordance with those obtained by Jaiswal et al. (2017), Kiran and Alagundagi (2018), 
Sharma et al (2019), Bajaniya et al (2019) and Ali et al (2020).

\section{$\underline{\text { 100-grain weight }}$}

Considering 100-grain weight, data from Table 5 revealed that favourable sowing produced significantly heavier grain weight than late and very late sowing date. This could be due to that grain maturity may be affected by high temperatures and resulted in shrinked grains. Over all environments, the average 100-grain weight of all genotypes was 4.14 g. Among the genotypes, Giza 171 produced maximum 100-grain weight (4.74 $\mathrm{g})$, which is statistically at par with Gimmaza 11 (4.71 g), minimum 100-grain weight (3.72 g) was produced by the genotype Masr 2 (Table 5). Delay the sowing of wheat decreased the 100-grain weight similar results were line up with Marasini et al (2010), Bankar et al (2018), Bachhao et al (2018), Patel et al (2019) and Ali et al (2020).

\section{Grain yield, Ard/fed.}

The combined analysis of variance (Table 3) indicated significant effect in grain yield as influenced by planting, years and genotypes studied. The normal sowing date gave 15.18 compared with 12.48 and 5.54 Ard/fed produced from late and very late planting dates, respectively (Table 5). Genotypes showed differential responses for either dates or years for grain yield (Table 5). Over all environments, the average grain yield of the genotypes was $11.07 \mathrm{Ard} / \mathrm{fed}$. Among the genotypes, the higher grain yield (12.53 Ard/fed) was recorded by Gimmaza 11, which was found at par with Masr 1, Masr 2, Giza 171 and Sakha 95 (12.28, 11.66, 11.90 and 11.81Ard/fed, respectively) and significantly superior to remaining genotypes (Table 5). On mean basis, under timely and both late sowing conditions, Gimmaza 11 produced maximum grain yield (17.78, 14.73 and $5.06 \mathrm{Ard} / \mathrm{fed}$, respectively) compared to rest of genotypes. The results are in agreement with those reported by Sial et al (2005), Tahir et al (2009), Vahid et al (2010), Aslani and Mehrvar (2012), Parwaizalam et al (2013), Mahajan et al (2018), Bachhao et al (2018), Patel et al (2019) Ali et al (2020).

\section{$\underline{\text { Heat susceptibility index and sensitivity }}$}

Five genotypes; Masr 1, Masr 2, Masr 3, Sids 12 and Sids 14 exhibited heat susceptibility index less than one (less susceptible) and gave also values less than one (less sensitive) in sensitivity test (Table 5), since they gave intermediate yield compared to yield under normal ones. Similar results were obtained by Zakaria (1999), Taghian and Abo-Elwafa (2003), Ali (2006) and Ali et al (2020).

\section{Variance components}

Results in Table 3 showed that the phenotypic variance was higher than genotypic ones for all traits under study. The small difference between $\sigma^{2} \mathrm{~g}$ and $\sigma^{2} \mathrm{p}$ was observed for days to heading, plant height, and 100-grain weight, indicating that there was little influence of environmental factors on their phenotypic expression. Heritability in the broad sense $\left(h^{2} b\right)$ was high for these traits. The phenotypic variance is a good index of genotypic variance in these traits. Selection is also easy for these traits. Similar results were obtained by Singh et al (2013) and Elbasier et al (2019). On the other hand, the large difference between $\sigma^{2} g$ and $\sigma^{2} p$ 
Table 5. Average performance of 100-grain weight and grain yield for the 12 genotypes under different sowing dates over two years.

\begin{tabular}{|c|c|c|c|c|c|c|c|c|c|c|c|}
\hline \multirow{2}{*}{ No. } & \multirow{2}{*}{ Genotypes } & \multicolumn{4}{|c|}{ 100-grain weight (g) } & \multicolumn{6}{|c|}{ Grain yield (Ard./fed.) } \\
\hline & & $\mathrm{D}_{1}$ & $\mathrm{D}_{2}$ & $\mathrm{D}_{3}$ & Combined & $\mathrm{D}_{1}$ & $\mathrm{D}_{2}$ & $\mathrm{D}_{3}$ & Combined & $\mathrm{HSI}^{++}$ & $\mathrm{S}^{+++}$ \\
\hline 1 & Masr 1 & 4.67 & 4.13 & 3.70 & 4.16 & 16.18 & 12.97 & 7.71 & 12.28 & 0.82 & 0.88 \\
\hline 2 & Masr 2 & 4.08 & 3.64 & 3.45 & 3.72 & 15.21 & 13.79 & 5.97 & 11.66 & 0.95 & 0.96 \\
\hline 3 & Masr 3 & 4.70 & 4.10 & 3.25 & 4.02 & 13.36 & 11.06 & 5.13 & 9.85 & 0.96 & 0.85 \\
\hline 4 & Sids 12 & 4.23 & 3.98 & 3.62 & 3.94 & 14.30 & 11.98 & 5.31 & 10.53 & 0.98 & 0.93 \\
\hline 5 & Sids 13 & 4.27 & 3.89 & 3.47 & 3.87 & 14.35 & 13.27 & 4.79 & 10.80 & 1.04 & 0.99 \\
\hline 6 & Sids 14 & 4.50 & 4.28 & 3.72 & 4.17 & 14.77 & 13.24 & 5.81 & 11.28 & 0.95 & 0.93 \\
\hline 7 & BAG \#1 & 4.37 & 3.91 & 3.35 & 3.87 & 13.07 & 9.70 & 3.92 & 8.90 & 1.09 & 0.95 \\
\hline 8 & Giza 171 & 5.50 & 4.65 & 4.07 & 4.74 & 16.56 & 12.63 & 6.52 & 11.90 & 0.95 & 1.04 \\
\hline 9 & Sakha 95 & 4.78 & 4.23 & 3.62 & 4.21 & 16.96 & 12.06 & 6.42 & 11.81 & 0.97 & 1.09 \\
\hline 10 & KACHU*2 & 4.98 & 4.60 & 3.75 & 4.44 & 13.94 & 10.63 & 4.77 & 9.78 & 1.03 & 0.95 \\
\hline 11 & Gimmaza 11 & 5.52 & 4.74 & 3.88 & 4.71 & 17.78 & 14.73 & 5.06 & 12.53 & 1.12 & 1.32 \\
\hline 12 & Shandaweel 1 & 4.37 & 3.92 & 3.05 & 3.78 & 15.65 & 13.70 & 5.06 & 11.47 & 1.06 & 1.10 \\
\hline \multicolumn{2}{|c|}{ Mean } & 4.66 & 4.17 & 3.58 & 4.14 & 15.18 & 12.48 & 5.54 & 11.07 & - & - \\
\hline \multicolumn{2}{|c|}{$\mathrm{RLSD}_{0.05}$} & - & - & - & 0.19 & - & - & - & 0.97 & - & - \\
\hline \multicolumn{2}{|c|}{$\operatorname{RLSD}_{0.01}$} & - & - & - & 0.27 & - & - & - & 1.18 & - & - \\
\hline
\end{tabular}

$\mathrm{HSI}^{+}=$Heat susceptibility index and $\mathrm{S}^{++}=$Sensitivity to heat stress.

observed for grain yield, indicating that there was large influence of environmental factors on their phenotypic expression. A low heritability estimate was found for these traits. The low heritability estimate was attributed to the facts that yields were quantitative traits that were controlled by many genes (Elbasier et al; 2019).

In conclusion, these results declare significant effects of years, sowing dates and their different order interactions on the different genotypes for most of the studied traits. This means that the studied genotypes responded differently for sowing dates and years, which caused difficulty in demonstrating the significant superiority of any genotype for all dates, and years. Therefore, it may be informative to study the stability parameters of each genotype.

\section{Stability analysis:}

Mean squares of joint regression analysis of variance (Table 6) for days to heading and grain yield were significant $(\mathrm{p}<0.01)$ differences among genotypes and environments. This indicates that the presence of genetic and environmental variation of these traits. Moreover, partitions of the genotypes $\times$ environments interaction as indicated by Env. + $(\mathrm{G} \times$ Env.), Envi. (Linear) and genotypes $\times$ environments interaction had significant $(p<0.01)$ effects for these traits. The genotype $\times$ environment (Linear) was significant; therefore, the stability analysis was performed according to Eberhart \& Russell (1966). This reflects that the change in performance of a genotype from year to another or genotypes showed different responses to heading date and yield when growing in different environments. These findings are in agreement with those obtained by Hamam 
Table 6. Joint regression analysis of variance of 12 genotypes for days to heading and grain yield over six environments.

\begin{tabular}{|l|c|c|c|}
\hline \multicolumn{1}{|c|}{ S. O. V } & df & $\begin{array}{c}\text { Days to heading } \\
\text { (days) }\end{array}$ & $\begin{array}{c}\text { Grain yield/plant } \\
\text { (Ard/fed.) }\end{array}$ \\
\hline Genotypes (G) & 11 & $45.55^{\text {** }}$ & $7.41^{* *}$ \\
\hline Env.+ (G $\times$ Env.) & 60 & $139.10^{* *}$ & $38.07^{* *}$ \\
\hline Env. (Linear) & 1 & $8138.87^{* *}$ & $2115.15^{* *}$ \\
\hline G $\times$ Env. (Linear) & 11 & $7.05^{*}$ & $2.57^{*}$ \\
\hline Pooled deviation & 48 & $2.70^{* *}$ & 0.54 \\
\hline Pooled error & 132 & 0.90 & 2.40 \\
\hline
\end{tabular}

*,** Significant at 0.05 and 0.01 probability levels, respectively.

and Abdel-Sabour (2009), Parveen et al. (2010), Mohamed and Said (2014) and Abd El-Rady and Koubisy (2017).

\section{Days to heading}

Respecting days to heading, the regression coefficient $\left(b_{i}\right)$ and deviation from regression $\left(S^{2} d_{i}\right)$ for five genotypes; Masr 3, BAG\#1, Giza 171, Sakha 95 and KACH4*2were insignificant from unity and zero, respectively (Table 7 and Fig. 1), showing that these genotypes considered to be stable for this trait. Two of them (BAG\#1 and $\mathrm{KACHU}^{* 2}$ ) were also stable for grain yield. According to Eberhart \& Russell (1966), the genotype KACHU*2 considered to be superior because the regression coefficient of this genotype equal one $\left(b_{i}=1\right)$, deviation from regression $\left(S^{2} d_{i}\right)$ were insignificant from zero and a low (earlier) mean when compared with the mean overall genotypes. Therefore, this wheat genotype could be grown under a wide range of environments (sowing dates). The regression coefficient value was deviated insignificantly and more than unity $\left(b_{i}>1\right)$ in variety Masr 3, indicating relatively suitable in favourable environments, normal sowing date and other inputs.
Meanwhile, the $b_{i}$ values deviated insignificant and less than unity $($ bi $<1)$ in the genotypes BAG\#1 and Giza 171. Thus, they were adapted to late (13 ${ }^{\text {th }}$ of Dec.) and very late sowing dates ( $16^{\text {th }}$ of January). The remainder genotypes were unstable (Table 7 and Fig. 1). These findings are in agreement with those obtained by Ram et al (2010), Mohamed and Said (2014) and Abd El-Rady and Koubisy (2017).

\section{Grain yield (Ard/fed)}

The stability parameters (Table 7 and Fig. 2) showed that the genotypes varied in theirb $b_{i}$ values as well as $S^{2} d_{i}$. It noticed that the intermediate yielding genotypes (Masr 1, Masr 2, Sids 12, Sids 13, Sids 14, BAG\#1 and KACHU*2) were stable and ranged in grain yield from 8.90 to $12.53 \mathrm{Ard} /$ fed. According to Eberhart \& Russell (1966) the variety Masr 2 and Sids 14 considered to be superior because the regression coefficient of this genotype equal one $\left(b_{i}=1\right)$, the deviation from regression $\left(S^{2} d_{i}\right)$ was insignificant from zero and a high mean when compared with the mean overall genotypes. Therefore, these wheat genotypes could be grown under a wide range of environments. The regression coefficient value was deviated 
Table 7. Stability parameters for days to heading and grain yield of 12 genotypes over six environments.

\begin{tabular}{|c|c|c|c|c|c|c|c|}
\hline \multirow{2}{*}{ No. } & \multirow{2}{*}{ Genotypes } & \multicolumn{3}{|c|}{ Days to heading } & \multicolumn{3}{c|}{ Grain yield } \\
\cline { 3 - 8 } & & $(\overline{\mathrm{X}})$ & $\mathrm{b}_{\mathrm{i}}$ & $\mathrm{S}^{2} \mathrm{~d}$ & $(\overline{\mathrm{X}})$ & $\mathrm{b}_{\mathrm{i}}$ & $\mathrm{S}^{2} \mathrm{~d}$ \\
\hline 1 & Masr 1 & 77.78 & 0.96 & $2.65^{*}$ & 12.28 & 0.87 & 0.16 \\
\hline 2 & Masr 2 & 81.00 & 0.97 & $5.15^{* *}$ & 11.66 & 1.00 & -0.07 \\
\hline 3 & Masr 3 & 75.33 & 1.10 & 0.95 & 9.85 & $0.54^{* *}$ & $5.71^{* *}$ \\
\hline 4 & Sids 12 & 74.72 & $1.12^{*}$ & $3.58^{* *}$ & 10.53 & 0.98 & 0.61 \\
\hline 5 & Sids 13 & 78.61 & $0.99^{*}$ & 0.85 & 10.80 & 1.07 & 0.75 \\
\hline 6 & Sids 14 & 80.33 & $1.15^{* *}$ & 0.37 & 11.28 & 1.05 & 0.26 \\
\hline 7 & BAG \#1 & 71.72 & 0.76 & 0.33 & 8.90 & 0.99 & -0.05 \\
\hline 8 & Giza 171 & 76.56 & 0.95 & 1.08 & 11.90 & 1.21 & $2.45^{* *}$ \\
\hline 9 & Sakha 95 & 79.11 & 0.96 & 1.37 & 11.81 & 1.11 & $1.37^{*}$ \\
\hline 10 & KACHU*2 & 74.00 & 1.04 & 0.41 & 9.78 & 0.95 & 0.10 \\
\hline 11 & Gimmaza 11 & 74.17 & 0.97 & $2.34^{*}$ & 12.53 & 0.99 & $8.53^{* *}$ \\
\hline 12 & Shandaweel 1 & 77.06 & 1.04 & $2.47^{*}$ & 11.47 & $1.24^{*}$ & 0.56 \\
\hline \multicolumn{2}{|c|}{ Mean } & 76.70 & - & - & 11.07 & - & - \\
\hline \multicolumn{2}{|c|}{ R. L. S. D. 0.05 } & 1.84 & - & - & 1.81 & - & - \\
\hline \multicolumn{2}{|c|}{ R. L. S. D. 0.01 } & 2.53 & - & - & 2.49 & - & - \\
\hline
\end{tabular}

*, ** Significantly from unity for $\left(\mathrm{b}_{\mathrm{i}}\right)$ and from zero for $\left(\mathrm{S}^{2} \mathrm{~d}\right)$ at 0.05 and 0.01 probability levels, respectively.

insignificantly and more than unity $\left(b_{i}>1\right)$ in varieties Sids 14, indicating relatively suitable in favourable environments, normal sowing date and other inputs. While, the variety Masr 1 was performed consistently less in favourable environments $\left(b_{i}<1.0\right)$ (Table 7 and Fig. 2). The remainder genotypes were unstable (Table 7 and Fig. 2).

It is clear that the highest yielding variety Gimmaza 11, which was unstable, performed well under normal sowing date (17.78 Ard/fed). Moreover, the same previous genotype also was the best under late $\left(13^{\text {th }}\right.$ of Dec.) and very late $\left(16^{\text {th }}\right.$ of January) sowing date (14.73 and $5.06 \mathrm{Ard} / \mathrm{fed}$, respectively). Under conditions such as exist late (16 $6^{\text {th }}$ of Dec.) and very late (23 $3^{\text {rd }}$ of January) sowing dates; the breeder was obliged to recommend the highest yielding genotype (Gimmaza 11) for such specific environments irrespective of their stability parameters. These results are in line with those reported by Okuyama et al (2005), Ali (2006), Hamam and Khaled (2009), Ram et al (2010), Abd ElShafi et al (2014), El-Moselhy et al (2015), Hamam et al (2015), Ali (2017), Khan et al (2018) and Ahmed et al (2019).

\section{Conclusion}

This study revealed that timely sown wheat crop (normal date, $23^{\text {rd }}$ of Nov.) showed highest growth parameters (days to heading and plant height) and yield attributing 


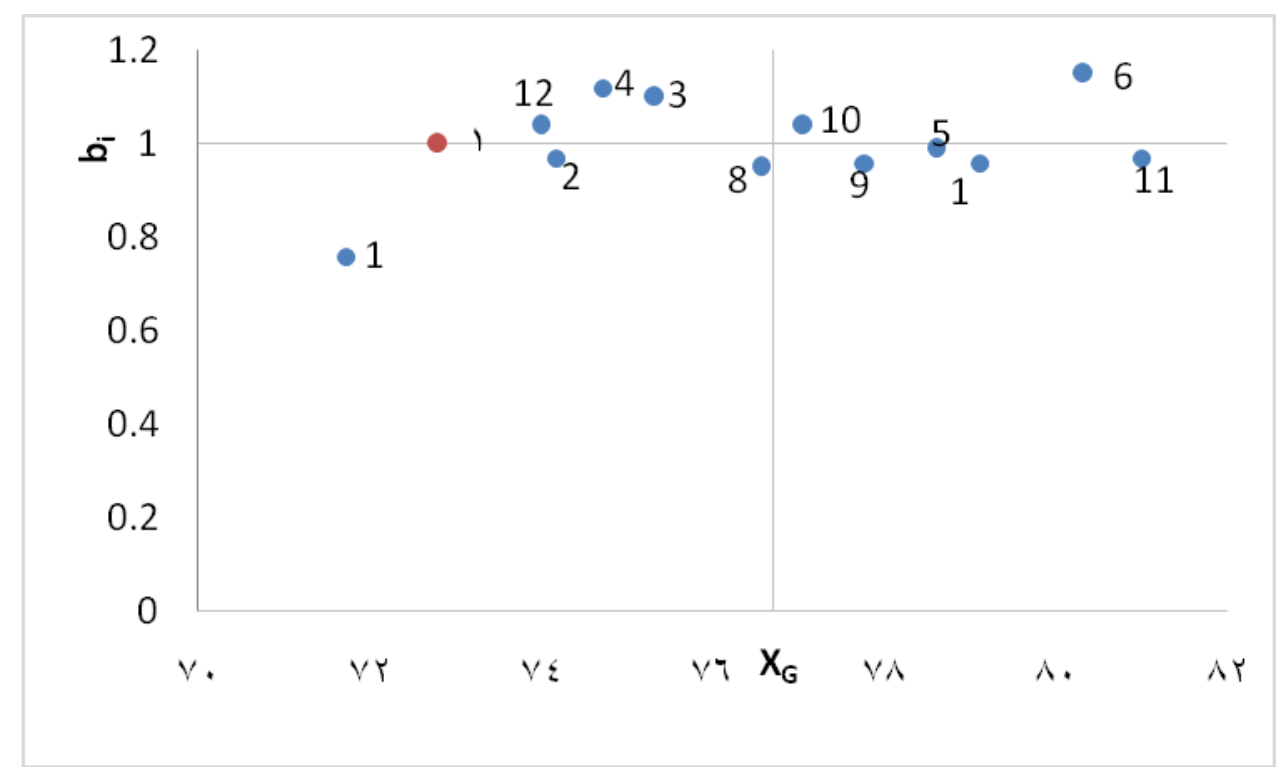

Fig. 1. Graphical illustration of the stability parameter $\left(b_{i}\right)$ and the mean performance of individual genotypes $(\overline{\mathrm{X}})$ for days to heading.

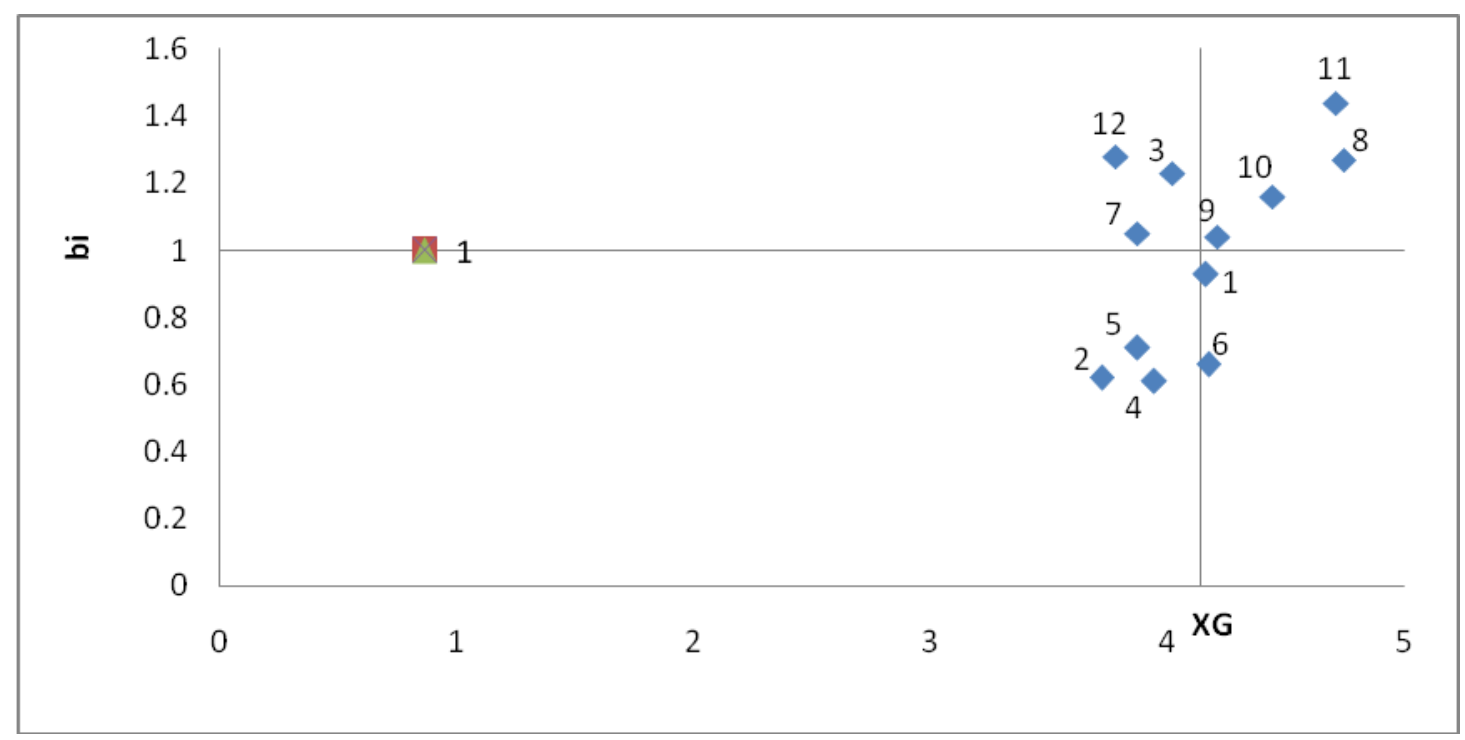

Fig. 2. Graphical illustration of the stability parameter $\left(b_{i}\right)$ and the mean performance of individual genotypes $(\overline{\mathrm{X}})$ for grain yield.

characters (100-grain weight and grain yield) compared to late $\left(13^{\text {th }}\right.$ of Dec.) and very late $\left(16^{\text {th }}\right.$ of January) sown crop. Among the genotypes under study, Giza 171 and Sakha 95 performed better in terms of grain yield, 100-grain weight and plant height especially under late sowing conditions. Hence, from the above study, it may be conclude that under normal sown condition any genotypes i.e., Masr 1, Masr 2, Masr 3, 
Sids 12, Sids 13, Sids 14, BAG\#1, Giza 171, Sakha 95, KACHU*2, Gimmaza 11 and Shandaweel 1 can be recommend. However, under late sown condition Giza 171 and Sakha 95 can be recommend for higher grain yield, 100-grain weight and plant height. The stability analysis revealed that the intermediate yielding genotypes (Masr 1, Masr 2, Sids 12, Sids 13, Sids 14, BAG\#1 and KACHU*2) were stable under different environments and ranged in grain yield from 13.20 to $17.82 \mathrm{Ard} / \mathrm{fed}$. These genotypes could be

\section{References}

Abd El-Rady, A. G. and Koubisy Y. S. I. (2017) 'Performance and stability of some durum wheat genotypes under different sowing dates and nitrogen fertilizer levels' Alex. J. Agric. Sci., pp. 259 - 271.

Abd El-Shafi, M. A., Gheith E. M. S., Abd El-Mohsen A. A. and Suleimen H. S.(2014) 'Stability analysis and correlations among different stability parameters for grain yield in bread wheat' Egypt J. Plant Breed., 18(1): pp. $83-93$.

Ahmad, A., KhanA. S., Kashif M. and Rehman M. A. (2017) 'Genetic studies of biomass partitioning in wheat under water stress' J. of Anim. and Plant Sci., 27(1): pp. 144 - 152.

Ahmed, H. G. M., Azmat M. A., Rizwan M., Maqsood R. H. and Khan S. H. (2019) 'Selection criteria for droughttolerant bread wheat genotypes at seedling stage' Sustainability, 11: pp. $1-17$.

Ali, M. A. (2006) 'Combining ability and stability analysis in spring wheat under four level of soil available useful in wheat improvement programs for enhancing stability. Meanwhile, the highest yielding variety; Gimmaza 11, which was unstable, performed well under normal, late and very late sowing dates (17.78, 14.73 and 5.06 Ard/fed, respectively). Under conditions such as exist late $\left(13^{\text {th }}\right.$ of Dec.) and very late $\left(16^{\text {th }}\right.$ of January) sowing date; the breeder was obliged to recommend the highest yielding genotype (Gimmaza 11) for such specific environments irrespective of their stability parameters.

water' Assiut J. Agric. Sci., 37(2): pp. $95-118$.

Ali, M. A. (2017) 'Stability analysis of bread wheat genotypes under different nitrogen fertilizer levels' $\mathrm{J}$. Plant Prod., Mansoura Univ., 8 (2): pp. $261-275$.

Ali, M. A.; Hassan M. S. and Ali I. A. (2020) 'Combining ability of some wheat genotypes under different environments' SVU-International J. of Agricultural Science 2 Issue (2): pp. $291-306$.

Al-Jibouri, H. A., Miller P. A.and Robinson H. F. (1958) 'Genotypic and environmental variances and covariance in an upland cotton crosses of interspecific origin' Journal of Agronomy,50: pp. 633 637.

Al-Otayk, S. M. (2010) 'Performance of yield and stability of wheat genotypes under high stress environments of the central region of Saudi Arabia' JKAU: Met., Env. \& Arid Land Agric. Sci., 21: pp. 81 92. 
Aslani, F. and Mehrvar M. R. (2012) 'Responses of wheat genotypes as affected by different sowing dates' Asian Journal of Agricultural Sciences 4(1): pp. 72-74.

Asmaa M., Badr M. F., Ahmed, Esmail A. M. and Rashed M. A. (2018) 'Heat tolerance in some bread wheat genotypes under two sowing dates' Arab Univ. J. Agric. Sci., Ain Shams Univ., Cairo Special Issue, 26(2A): pp. $987-1000$.

Bachhao, K. S., Kolekar P. T., Nawale S. S. and Kadlag A. D. (2018) 'Response of different wheat varieties to different sowing dates' Journal of Pharmacognosy and phytochmistry; 7(1): pp. 2178 - 2180.

Bajaniya, N., Pansuriga A. G., Vekaria D. M., Singh C. and Savaliga J. J. (2019) 'Combining ability for grain yield and its components in durum wheat (Triticum durum Desf.)' Ind. J. Pure App. Biosci. 7: pp. 217 - 224.

Bankar, D. N., Baviskar V. S., Kumar K. J. Y., Raskar S. S., Khairnar S. S., Gite V. D., Surve V. D., Bagwan J. H. and Honrao B. K. (2018) 'Evaluation of wheat (Triticum aestivum L.) genotypes for changing climatic condition under different sowing windows in semi-arid tropics of Western Maharashtra' India. Int. J. Curr. Microbiol. App. Sci. 7(4): pp. $761-770$.

Berke, T. G.; P. S. Baenziger and Morris R. (1992a) 'Chromosomal location of wheat quantitative trait loci affecting agronomic performance of seven traits using reciprocal
Chromosome substitutions'

Crop Sci. 32: pp. 621- 627.

Comstock, R. R. and Robinson H. F. (1952) 'Genetic parameters, their estimation and significance' Proceedings of th $6^{\text {th }}$ international Grassland Congress, Vol, Nat. publ. Co., Washington, DC, pp. 248 - 391.

Dokuyucu, T., Akkaya A. and Yigitoglu D. (2004) 'The effect of different sowing dates on growing periods, yield and yield components of some bread wheat (Triticum astivum L.) cultivars grown in the EastMediterranean region of Turkey' J. of Agronomy. 3(2): pp. 126 - 130.

Eberhart, S. A. and Russell W. A. (1966) 'Stability parameters for comparing varieties' Crop. Sci., 6(1): pp. 36 - 40.

Elbasier, E. M., Elbasier E. M. E., Idris S. E.,Tadesse W.,Tahir I. S. A., Ibrahim A. S., Elhashimi A. M. A., Saad S. I., Idris A. A. and Mustfa H. M. (2019) 'Genetic variations, heritability, heat tolerance indices and correlations studies for traits of bread wheat genotypes under high temperature' International J. of Climate Change Strategies and Management. Vol., 11(5): pp. 672 686.

El-Moselhy, O. M., Ali A. G., Awaad H. A. and Sweelam A. A. (2015) 'Phenotypic and genotypic stability for grain yield in bread wheat across different environments' Zagazig J. Agric. Res., 42(5): pp. 913 - 926.

El-Rawi, K. and Khalafalla A. M. (980) 'Design and analysis of agricultural experiments' El Mousel Univ., Iraq, 19. 
Falconer, D. S. (1990) 'Selection in different environment: effects on environmental sensitivity (reaction norm) and mean performance' Genrt. Res. Camb., 56: pp. 57-70.

Fisher, R. A. and Maurer R. O. (1978) 'Drought resistance in spring wheat cultivars. 1- Grain yield responses' Aust. J. Agric. Res.; 29: pp. 897 912.

Gomez, K. A., and Gomez A. A. (1984) 'Statistical procedures for Agricultural Research' John Wiley \& Sons Inc. New York, USA.

Guttieri, M. J., Stark J. C., Brien K. O. and Souza E. (2001) 'Relative sensitivity of spring wheat grain yield and quality parameters to moisture deficit' Crop Sci., 41: pp. 327 - 335.

Hakim, M. A.,HossainA., da SilvaJ. A. T.,ZvolinskyV. P. and Khan M. M. (2012) 'Yield, protein and starch content of twenty wheat (Triticum aestivum L.) genotypes exposed to high temperature under late sowing conditions' J. Sci. Res., 4 (2): pp. 477 $-489$.

Hamada and Ibrahim K. A. M. (2016) 'Heat stress impact and genetic diversity among some bread wheat genotypes' Egypt. J. Agron. 38, No. 3, pp. $389-412$.

Hamam, K. A. and Khalid A. G. A. (2009) 'Stability of wheat genotypes under different environments and their evaluation under sowing dates and nitrogen fertilizer levels' Aus. J. of Basic and Applied Sciences, 3(1): pp. 206 $-217$.
Khan, F. A, Khan M. I., Khan S., Zaman M. A., Rasheed H. and Abdul-Rahim K. (2018) 'Evaluation of agronomic traits for yield and yield components in wheat genotypes with respect to planting dates' Malaysian J. of Sustainable Agriculture (MJSA) 2(1): pp. $07-11$.

Hamam, K. A., Khaled A. G. A. and Zakaria M. M. (2015) 'Genetic stability and diversity in yield components of some wheat genotypes through seasons and heat stress under different locations' J. Plant Prod., Mansoura Univ., 6 (3): pp. 349 - 370.

Jaiswal, B., Prasad S., Dwivedi R., Singh S., R., Shrivastava S., Kumar A. and Yadav R. K. (2017) 'Study of yield and yield components of wheat (Triticum aestivum L.) genotypes at grain filling stage under heat regimes' Int. J. Pure App. Bio. sci., 5(4): pp. $331-340$.

Khajuria, P., Singh A. K., Singh R. (2016) 'Effect of heat stress on grain weight in bread wheat' Indian j. of Applied Research Agriculture 6(1): 2249$555 x$.

Kiran, R. G. and Alagundagi S. C. (2018) 'Response of bread wheat (Triticum aestivum L.) genotypes to date of sowing and nutrient management for growth and yield under late sown irrigated condition' Journal of Pharmacognosy and Phytochemistry, 7(6): 345 - 348.

Marasini, D., Marahatta S., Dhungana S. M. and Acharya R. (2016) 'Effect of sowing on yield and yield attributes of different wheat varieties under 
conventional tillage in sub-humid condition of Chitwan district of Nepal' International Journal of Applied Science and Biotechnology, 4(1): 27 - 31.

Mwadzingeni, L., Shimelis H. and Tsilo T. J. (2018) 'Combining ability and gene action controlling yield and yield components in bread wheat (Triticum aestivum L.) under drought-stressed and non-stressed conditions' Plant Breeding/ 137, issue 4.

Mohamed, N. E. M. and Said A. A. (2014) 'Stability parameters for comparing bread wheat genotypes under combined heat and drought stress' Egypt J. Agron., 36(36): 123146.

Mukherjee, D., Kumar M., Das GK. And Mukherjee S. C. (2018) 'Effect of weather parameter on growth and yield of wheat under different growing environment in bastar plateau zone' International $J$. of Chemical Studies. 6(6): 1080 - 1085.

Okuyama, L. A., Federizz L. C. and Neto G. F. B. (2005)' Grain yield stability of wheat genotypes under irrigated and non-irrigated conditions' Braz. Arch. Biol. Technol., 697 - 704.

Oliveira, D. M. de, Souza, M. A. de, Rocha V. S., Assis J. C. de (2011) 'Performance of wheat genitors and segregating populations under heat stress' [Portuguese]. Bragantia; 70(1): $25-32$.

Parveen, L., Khalil I. H. and Khalil S. (2010) 'Stability parameters for tillers, grain weight and yield of wheat cultivars in North-West of Pakistan' Pak. J. Bot., 42(3): 1613 1617.

Parwaizalam, A., Satyender K., Ali N., Ramprasad M., Nargisand K. and Rajni KL. (2013) 'Performance of wheat varieties under different sowing dates in Jharkhand, Birsa Agricultural University, Ranchi' Journal of Wheat Research, 5(2): 61 64

Patel, S. K., Patel P. M., Patel J. K. and Gohil V. B. (2019) 'Response of wheat (Triticum aestivum L.) to sowing time with varying levels of spacing' International Journal of Chemical Studies. 7(4): 08 - 10. Phytochemistry, 7(1): 2178 - 2180.

Ram, C., Sharma I., Alexei I., Morgounov, Hans J. and Braun (2010) 'Identifying high yielding stable winter wheat genotypes for irrigated environments in Central and West Asia' Euphytica, 171: 53 - 64.

Shah, WA; J. Bakht; T. Ullah; AW. Khan; M. Zubair and A. Khakwani. 2006. 'Effect of sowing dates on yield and yield components of different wheat varieties' J Agron., 5 (1): 106 - 110.

Shahzad, K., Bakht J., Shah W. A., Shafi M. and Jabeen N. (2002) 'Yield and yield components of various wheat cultivars as affected by different sowing dates' Asian J. of Plant Sci., 1(5): 522 - 525.

Sharma, CS., Morgounov AI., Braun HJ., Akin B., Keser M., Bedoshvili D., Bagci A., Martius C. and Van Ginkel M. (2010) 'Identifying high yielding stable winter wheat genotypes for irrigated environments in Central and West Asia' Euphytica, 171, 1, 53-64. 
Sharma Y., Dodiga N. S., Dubey R. B. and Khan R.(2019) 'Combining ability analysis in bread wheat (Triticum aestivum L.) EM.Thell) under different environmental conditions' Bangladesh J. Bot. 48: pp. 89-93.

Sial, M. A., Arian M. A., Khanzada S., Naqvi M. H., Dahot M. U. and Nizamani N. A. (2005) 'Yield and quality parameters of wheat genotypes as affected by sowing dates and high temperature stress' Pak. J. Bot., 37(3): 575.

Singh, J. B., Vermen A., Prakash S., PatidarI., Prakash T. L., Prasad S. S., Singh A. K. and Mishra A. N. (2013) 'Variability and interrelation ship analysis in bread wheat under moisture stress conditions' J. Wheat Res. 5(2): 27 - 34.

Singh, S. and Pal M. (2003) 'Growth, yield and phenological response of wheat cultivars to delayed sowing' Indian J. of Plant Physiology. 8(3): $277-286$.

Taghian, A. S. and Abo-Elwafa A. (2003) 'Multivariate and RAPD analysis of drought tolerance in spring wheat (Triticum aestivum L)' Assiut J. of Agric. Sci., 34(5): 1 - 25.

Tahir, M., Ali A., Ather M., Akhter N., Hussainand Khalid F. (2009) 'Effect of different sowing dates on growth and yield of wheat (Triticum astivum L.) varieties in district Jhang, Pakistan Department of Agronomy, University of Agriculture FaisalabadPakistan' Pakistan J. of life and social sciences, 7(1): 66 - 69 .
Tammam, A. M. and Abd EL-Rady A. G. (2011) 'Genetical studies on some morpho-physiological traits in some bread wheat crosses under heat stress conditions' Egypt. J. Agric. Res., 89 (2).

Vahid, K., Nejad G. Kh., Nejad G. M. and Yousefi Kh. (2010) 'The effect of different sowing dates on yield and yield components of wheat (Triticum astivum L.) cultivars' International Journal of Agronomy and Plant Production, 1(3): 77 - 82.

Wajid, A. Sh., Bakht J., Ullah T., Khan A. W., Zubair M. and Khakwani A. (2006) 'Effect of sowing dates on the yield and yield components of different wheat varieties' Journal of Agronomy, 5(1): 106 - 110.

Zakaria, M. M. (1999) 'Genetical and agronomic studies on heat tolerance and yield in wheat (Triticum aestivum L.). M.Sc. Thesis, Fac. of Agric., Assiut Univ. 